\title{
Persepsi Petani terhadap Aspek Teknis Komoditi Kelapa Sawit. di Desa Ladang Peris Kecamatan Bajubang Kabupaten Batanghari.
}

\section{Perception of Farmers in Technical Aspects of Oil Palm Commodity in Ladang Peris village, District Bajubang, Batanghari District)}

\author{
Shinta Anggreany ${ }^{1}$, Arsyad Lubis $^{2}$, Idris Sardi ${ }^{2}$ \\ ${ }^{1}$ Program Studi Ilmu Penyuluhan Pembangunan, Sekolah Pascasarjana, Institut Pertanian Bogor \\ 23 Jurusan Agribisnis, Fakultas Pertanian, Universitas Jambi
}

\begin{abstract}
The cultivation of oil palm in the Province of Jambi is growing rapidly, this condition influenced by the farmer's decision to select the commodity in farming. The decision influenced by the thair perceived, knowledge and experience. The technical aspects include time needed incultivation practice and harvesting, and knowledge of pests and diseases. This research aimed to analyze the perception of the palm in technical aspects. This research was conducted in Ladang Peris village, District Bajubang, Batanghari District with 29 respondents from May 26, 2011 until. June 26, 2011. Data analysis is based on qualitative methods. The results showed that the perception of farmers on the tecnical aspects of oil palm focused on easy cultivation practice, harvesting once in two weeks period, and less pests and diseases infestation as compared to rubber plant.
\end{abstract}

Keywords: Perception of farmers, technical aspects, palm

\begin{abstract}
Abstrak
Perkembangan komoditi kelapa sawit yang kian pesat khususnya di Provinsi Jambi yang dipengaruhi oleh keputusan petani untuk memilih mengembangkan komoditi dalam usahataninya. Keputusan tersebut di pengaruhi oleh persepsi yang merupakan anggapan terhadap sesuatu berdasarkan pengetahuan dan pengalaman yang dimiliki. Persepsi terhadap suatu objek yang dimikili setiap orang berbeda satu sama lain, termasuk dalam melihat aspek teknis usahatani kelapa sawit. Aspek teknis meliputi cara melakukan budidaya, waktu yang dibutuhkan petani dalam perawatan dan pemanenan, pengetahuan tentang hama dan penyakit serta mudah tidaknya usahatani tersebut dikembangkan menurut petani. Penelitian ini bertujuan untuk menganalisis persepsi petani terhadap komoditi kelapa sawit ditinjau dari aspek teknis. Penelitian ini dilakukan di Desa Ladang Peris, Kecamatan Bajubang, Kabupaten Batanghari dengan jumlah responden 29 orang petani, sejak tanggal 26 Mei 2011 sampai tanggal 26 Juni 2011. Analisis data dilakukan dengan metode kualitatif. Hasil penelitian menunjukkan bahwa persepsi petani terhadap komoditi kelapa sawit ditijau dari aspek teknis yaitu menguntungkan karena teknik budidaya yang mudah. Pada saat pemanenan hanya dibutuhkan waktu 1 kali dalam 2 minggu, organisme pengganggu tanaman dan hama penyakit tanaman lebih sedikit, petani membandingkan dengan tanaman karet yang dimilikinya mudah terkena Jamur Akar Putih yang sulit dikendalikan dan hal tersebut tidak terjadi pada kelapa sawit.
\end{abstract}

Kata kunci: Persepsi petani, aspek teknis, kelapa sawit

\section{Pendahuluan}

Perkembangan sektor perkebunan Di Provinsi Jambi mengalami peningkatan yang cukup signifikan terutama perkebuanan karet dan kelapa sawit. Provinsi Jambi dahulunya dikenal dengan komoditi karet yang merupakan komoditi unggulan perkebunannya namun sejak masuknya komoditi kelapa sawit ke Provinsi Jambi tahun 1985 banyak petani yang ikut mengusahakan komoditi kelapa sawit. Setiap tahun terjadi peningkatan luas lahan perkebunan kelapa sawit yang cukup signifikan di Provinsi Jambi.

Menurut Sunarko (2008) minyak kelapa sawit memiliki prospek pemasaran yang cukup menjajikan di dunia. Hal ini sejalan dengan pendapat Fauzi et al., (2008) yang menyatakan bahwa Minyak kelapa sawit dapat dikembangkan sebagai salah satu bahan bakar dan digunakan untuk kebutuhan bahan baku industri, seperti industri pangan serta industri non-pangan, seperti kosmetik dan farmasi. Perkembangan komoditi kelapa sawit dinilai cukup menjanjikan apabila dikelola dengan baik. Kesesuaian lahan juga menjadi pertimbangan dalam mengembangkan komoditi kelapa sawit seperti di wilayah Indonesia yang pada umumnya sangat cocok untuk pengembangan komoditi kelapa sawit tersebut.

Di Kabupaten Batanghari komoditi kelapa sawit mulai berkembang baik yang bekerja sama

${ }^{1}$ Korespondensi penulis E-mail: Shintaanggreany@gmail.com 
dengan perusahaan maupun mandiri (kebun sawit milik pribadi). Salah satunya di Kecamatan Bajubang yang memiliki luas pengembangan perkebuanan kelapa sawit nomor dua terbesar di Kabupaten Batanghari setelah wilayah Kecamatan Mersam namun memiliki produksi tertinggi di bandingkan dengan seluruh kecamatan di kabupaten Batanghari. Perluasan lahan perkebunan kelapa sawit terus meningkat. Pada tahun 2008 luas lahan di Kecamatan Bajubang mencapai 14.442 Ha dengan produksi 36.999 ton yang merupakan produksi tertinggi di Kabupaten Batanghari di bandingkan dengan kecamatan lainnya.

Di Kecamatan Bajubang yang terdiri dari 9 desa dan masing-masing desa memiliki perkebunan kelapa sawit. Desa Ladang Peris merupakan desa yang memiliki luas perkebunan kelapa sawit terbesar di Kecamatan Bajubang dengan luas lahan mencapai $112 \mathrm{Ha}$ dan produksi mencapai 1.250 ton dan desa ini mewakili salah satu desa di Kecamatan Bajubang yang dijadikan sebagai lokasi penelitian. Peningkatan perluasan areal perkebunan kelapa sawit secara tidak langsung dipengaruhi oleh banyaknya petani yang mengusahakan kelapa sawit sebagai komoditi yang dikembangkan dalam usahataninya. Hal ini tentu saja dipengaruhi oleh pola fikir dan pandangan petani terhadap komoditi kelapa sawit. menurut hasil penelitian Kholiq et al. (2008), mengemukakan bahwa persepsi terhadap lumbung pangan juga dilihat dari bagaimana pandangan serta penilaiannya terhadap lumbung pangan, pengetahuan masyarakattentang lumbung pangan, kemudian. Selaras dengan pendapat tersebut Chapin dalam Hadiwijaya (2011) mengemukakan bahwa persepsi merupakan sebuah proses mengetahui dan mengenali objek serta kejadian yang bersifat objektif dengan bantuan alat indra.

Persepsi para petani dalam mengusahakan komoditi kelapa sawit tentu saja dikarenakan berbagai alasan dan berbagai pandangan terhadap komoditi tersebut, seperti pada aspek teknis. Namun, sebelum mempersepsikan sesuatu petani terlebih dahulu mendapatkan rangsangan yang bisa berbentuk informasi dari PPL, media massa maupun mengamati lingkunganya. Petani cenderung melihat suatu komoditi dari nilai ekonomi yang mampu dihasilkan oleh kododiti tersebut, namun terdapat pula rangsangan-rangsangan lainnya baik yang datang dari luar (eksternal) diri petani maupun yang datang dari dalam (internal)diri petani yang mempengaruhi persepsi petani. Dalam mengusahakan usahatani kelapa sawit petani memiliki persepsi yang berbedabeda terhadap komoditi kelapa sawit. Sementara itu sebelum petani memiliki persepsi terhadap suatu masalah tertentu maka terdapat berbagai latar belakang yang mempengaruhi persepsi tersebut. Persepsi bersifat individu yang artinya setiap individu memiliki persepsi yang berbeda-beda terhadap suatu objek atau fenomena. hasil penelitian Hamid et al. (2013) mengemukakan bahwa persepsi yang positif dari masyarakat menggambarkan bahwa masyarakat dapat mengadosi inovasi pertanian dalam kehidupannya, sehingga berdampak positif pada aspek ekonomi dan aspek sosial masyarakat tersebut.

Saat ini petani cenderung mempersepsikan komoditikelapasawitdariaspekbesarnyakeuntungan dibandingkan dengan aspek teknik. Pilihan yang dominan terhadap komoditi kelapa sawit pada saat melakukan penanaman lalu memunculkan persepsi tersendiri terhadap fenomena ini. Mengapa petani sangat berminat untuk mengembangkan komoditi kelapa sawit dibandingkan dengan komoditi lain seperti karet dan tanaman perkebunan lain. Apa yang dipersepikan petani tentang komoditi kelapa sawit, khususnya dari aspek teknis.

Aspek teknis merupakan hal yang sangat penting karena berhubungan dengan pengelolaan dan teknik budidaya yang digunakan petani dalam melakukan usahataninya. Berdasarkan latar belakang tersebut, maka tujuan dari penelitian ini adalah untuk mengkaji dan menganalisis persepsi petani terhadap komoditi kelapa sawit ditinjau dari aspek teknis. Kegunaan dari penelitian ini diharapkan untuk dapat memberikan informasi dan masukan bagi pihak pemerintah dalam membuat kebijakan dan pengembangan kelapa sawit di Provinsi Jambi.

\section{Metode Penelitian}

Penelitian ini dilaksanakan di Desa Ladang Peris, Kecamatan Bajubang, Kabupaten Batanghari. Wilayah ini dipilih dengan pertimbangan karena di daerah ini merupakan daerah yang memiliki perkebunan kelapa sawit yang terluas di Kecamatan Bajubang. Responden penelitian ini adalah petani yang memiliki perkebunan kelapa sawit milik pribadi. Pengumpulan data ini dilaksanakan selama 
1 bulan, dari tanggal 26 Mei 2011 sampai tanggal 26 Juni 2011. Dalam hal ini data dan informasi yang diperlukan sebagian besar data yang bersifat kualitatif. Data dan informasi primer adalah data yang diperoleh secara langsung dari responden yang merupakan keseluruhan petani di Desa Ladang Peris yang mengusahakan komoditi kelapa sawit dan informan yang merupakan sasaran wawancara mendalam (indepth interview), serta observasi.

Di desa Ladang Peris terdapat 29 kepala keluarga (KK) petani yang mengusahakan komoditi kelapa sawit dan untuk keperluan penelitian ini semua petani yang mengusahakan komoditi kelapa sawit menjadi responden, dengan menggunakan metode sensus. Data yang diperoleh melalui kajian ini merupakan data kualitatif dan akan dianalisis secara kualitatif. Analisis data dalam penelitian ini berlangsung bersamaan dengan proses pengumpulan data, diantaranya mengikuti tiga jalur yaitu, reduksi data, penyajian data dan penarikan kesimpulan.

\section{Hasil dan Pembahasan}

Aspek teknis merupakan hal yang sangat penting karena berhubungan dengan pengelolaan, budidaya serta teknologi yang digunakan petani dalam melakukan usahataninya. Untuk melihat aspek teknis pengetahuan petani dapat digolongkan menjadi 2 yaitu petani yang berpendapat bahwa aspek teknis dalam usahatani kelapa sawit dikatakan mudah dan petani yang berpendapat bahwa aspek teknis dalam usahatani kelapa sawit dikatakan sulit diaplikasikan petani dilahan yang dimilikinya. Kemudahan budidaya tersebut mendorong petani untuk terus membudidayakan komoditi kelapa sawit begitu juga sebaliknya.

Sebagian besar petani mempersepsikan bahwa dari aspek teknis pada komoditi kelapa sawit tergolong mudah. Petani yang mempersepsikan aspek teknis usahatani kelapa sawit mudah lebih dari 90\% dari jumlah petani. Persepsi petani terhadap komoditi kelapa sawit dari aspek teknis bervariasi, dengan berbagai alasan yang ada seperti, petani mempersepsikan komoditi kelapa sawit menguntungkan dari aspek teknis dengan alasan bahwa teknik budidaya kelapa sawit tergolong mudah, pada saat pemenenan hanya dilakukan 2 minggu sekali bisa dikatakan lebih menghemat waktu sehingga pada waktu yang lain petani dapat mengerjakan aktivitas dan usaha yang lain sebagai upaya menambah penghasilan keluarga seperti berdagang, menyadap karet dan lain sebagainya.

Petani juga mempersepsikan bahwa dari aspek teknis OPT (organisme pengganggu tanaman) dan HPT (hama pengganggu tanaman) pada komoditi kelapasawitcenderung sedikit dan tidakmembutuhkan penanganan yang lebih serius dalam pengendalianya. Terdapat beberapa jenis jamur yang biasa menyerang tanaman karet petani di lokasi penelitian yaitu jamur akar putih, jamur akar merah dan jamur upas namun, yang paling sering ditemukan adalah jamur upas dan JAP. Petani juga mempersepsikan bahwa komoditi kelapa sawit lebih hemat bibit karena hama lebih sedikit dan dalam satu hektar lahan usahatani kelapa sawit tidak membutuhkan banyak bibit. Hal ini dapat mengurangi biaya pengangkutan dan biaya penanaman serta perawatan. Sementara petani membandingkan dengan tanaman karet yang dimilikinya, dimana pada tanaman karet terdapat jamur yang menyerang tanaman karet dan jamur tersebut sulit dikendalikan perkembanganya. Apabila ditanam tanaman karet kembali ditanam dilokasi yang pernah terserang jamur maka jamur yang sama akan menyerang tanaman karet yang baru tersebut sehingga petani memilih komoditi kelapa sawit sebagai alternatif usaha yang dikembangkanya.

Petani mempersepsikan komoditi kelapa sawit menguntungkan dari aspek teknis terdapat juga beberapa orang petani mempersepsikan bahwa komoditi kelapa sawit tidak menguntungkan karena hasil panen dalam bentuk TBS (Tandan Buah Segar) dari komoditi kelapa sawit tidak tahan lama dengan kata lain bersifat mudah busuk dan apabila busuk maka harga jual akan menurun dan petani bisa mengalami kerugian. Oleh sebab itu pemanenan kelapa sawit harus dilakukan secara rutin selama 2 minggu 1 kali. Petani juga membandingkan dengan tanaman karet, meskipun petani harus menyadap setiap hari namun karet yang dipanen tidak akan mengalami pembusukan apabila tidak langsung dijual ke pabrik dalam waktu yang cepat. Permasalahan tersebut memberikan pemahaman bagi petani sehingga petani biasa lebih giat dan serius dalam melakukan usahatani kelapa sawit dengan baik agar petani tidak mengalami kesulitan. Hasil penelitian Sihabudin et al. (2010), persepsi dinyatakan sebagai kesan atau anggapan terhadap sesuatu seperti sebuah bentuk objek, keadaan dan sebuah peristiwa. Kemudian hasil penelitian Kholiq 
Tabel 1 Frekuensi Persepsi Petani terhadap Komoditi Kelapa Sawit dari Aspek Teknis, Tahun 2011

\begin{tabular}{clcc}
\hline No & Persepsi Petani & Frekuensi (KK) & Persentase (\%) \\
\hline 1 & Mudah & 27 & 93,10 \\
2 & Sulit & 2 & 6,89 \\
\hline \multirow{2}{*}{ Jumlah } & & 29 & 100,00 \\
\hline
\end{tabular}

et al. (2008) tentang lumbung pangan, menemukan bahwa persepsi petani terhadap lumbung pangan juga dilihat dari apakah masyarakat mengetahui dan mengenal lumbung pangan atau tidak, selanjutnya bagaimana pandangan dan penilaian petani terhadap lumbung pangan. Sehingga terlihat jelas bahwa dalam hal ini, persepsi petani terhadap aspek teknis merupakan kesan yang dilihat petani ditinjau dari aspek teknis dan didasari oleh sejauh mana petani mengetahui aspek teknis dari komoditi kelapa sawit tersebut.

Petani yang mempersepsikan komoditi kelapa sawitmenguntungkanmemilikialasan yang bervariasi. Lebih dari 70\% Petani mengatakan bahwa dari teknis budidaya komoditi kelapa sawit lebih mudah. Tidak membutuhkan waktu yang banyak untuk perawatan. Teknis budidaya yang mudah yang dimaksud oleh petani adalah pada saat penanaman komoditi kelapa sawit hanya membutuhkan bibit dalam jumlah lebih sedikit dibandingkan komoditi karet sehingga untuk membuat lubang tanam, pemupukan, pembuatan piringan pada sekeliling batang, pengendalian gulma lebih mudah dibandingkan dengan komoditi karet.

Pada dasarnya teknis budidaya komoditi kelapa sawit dan komoditi karet memiliki tingkat kesulitan yang berbeda seperti pada saat proses pemanenan pada kelapa sawit yang berumur lebih dari 15 tahun akan lebih sulit karena pohon kelapa sawit lebih tinggi bahkan bisa mencapai 10 meter sehingga resiko keamanan kerja lebih besar, sementara itu untuk komoditi karet pada saat panen membutuhkan tingkat ketelitian yang cukup tinggi agar tidak melukai pembuluh kayu pada tanaman karet sehingga mempengengaruhi umur ekonomi tanaman karet.

Petani responden pada lokasi penelitian dalam mempersepsikan komoditi kelapa sawit memiliki teknik budidaya yang lebih mudah hanya berdasarkan pengamatan pada saat awal penanaman komoditi kelapa sawit, hal ini dikarenakan sebagian besar petani komoditi kelapa sawit di lokasi penelitian memiliki pengalaman berusahatani 1-10 tahun dan pada saat ini proses pemanenan masih menggunakan dodos yang berarti batang tanaman kelapa sawit belum terlalu tinggi dengan tingkat kesulitan yang kecil. Petani juga cenderung membandingkan tenik budidaya dengan tanaman perkebunan lainnya seperti tanaman karet. Hasil penelitian Edwina dan Maharani (2010) mengemukakan bahwa persepsi petani terhadap teknologi pengolahan pakan dikategorikan baik karena tingkat kerumitan yang rendah dengan kata lain teknologi yang digunakan sederhana dan memudahkan petani dlam mengaplikasikannnya. Dari penelitian tersebut terlihat jelas bahwa petani mempersepsikan sesuatu karena faktor mudah tidaknya sebuah teknologi tersebut diterapkan sama halnya dengan petani di Desa Ladang Peris.

Petani juga dapat membandingkan dengan komoditi pangan yang membutuhkan perlakuan yang lebih intensif dari pada kelapa sawit. Petani cenderung melihat petani lain yang berada dekat dengan Desa Ladang Peris yaitu di Kecamatan Sungai Bahar dan merupakan eks transmigrasi yang dipandang petani berhasil melakukan usahatani kelapa sawit dan dapat meningkatkan pendapatan serta kesejahteraan petaninya. Dari penjelasan tersebut membuktikan bahwa petani di Desa Ladang Peris cenderung membangun persepsi berdasarkan faktor imitasi. Menurut Gerungan (2009) adalah suatu bagian dari interaksi sosial yang menjelaskan mengapa dan bagaimana dapat terjadi keseragaman dalam pandangan dan tingkah laku diantara orang banyak. Oleh sebab itu interaksi sosial dalam masyarakat yang terjadi di Desa Ladang Peris terjadi salah satunya dikarenakan prilaku imitasi yang dimiliki masyarakat yaitu meniru orang lain dari sikap, perilaku, gaya, cara berfikir, penampilan, keterampilan, kemampuan, dan lain sebagainya. Perilaku ini dipengaruhi oleh adanya pandangan, pengamatan dan interpretasi petani dalam memaknai apa yang diamatinnya.

Lebih dari $75 \%$ petani yang berpendapat 
Tabel 2 Frekuensi Alasan Petani Mempersepsikan Komoditi Kelapa Sawit Menguntungkan Dari Aspek Teknis

\begin{tabular}{clcc}
\hline No & \multicolumn{1}{c}{ Alasan } & Frekuensi (KK) & Persentase (\%) \\
\hline 1 & Teknis Budidaya Mudah & 23 & 79,31 \\
2 & Panen 2 Minggu Sekali & 22 & 75,89 \\
3 & OPT dan HPT penganggu lebih sedikit & 14 & 48,27 \\
4 & Serangan jamur yang ada pada karet tidak menyerang kelapa sawit & 10 & 34,48 \\
\hline
\end{tabular}

bahwa komoditi kelapa sawit lebih hemat waktu dalam proses pengelolaanya karena pada saat proses pemanenan hanya dilakukan selama dua minggu sekali. Sementara itu untuk komoditi karet membutuhkan waktu yang lebih banyak karena harus disadap setiap hari. Petani menganggap komoditi karet untuk tahap pemanenan cenderung lebih merepotkan dari pada komoditi kelapa sawit. Menurut petani apabila petani mengusahakan komoditi kelapa sawit maka petani bisa memiliki waktu luang yang bisa dipergunakan untuk melakukan usaha lain untuk memenuhi kebutuhan keluarganya seperti berdagang dan lain sebagainya. Dalam hal ini terlihat bahwa petani sampel pada lokasi penelitian mempersepsikan alasan seperti yang telah dikemukakan di atas hanya karena mempertimbangkan ketersediaaan waktu pada saat pemanenan saja dan tidak mempertimbangkan alokasi waktu pada saat perawatan dan pengelolaan pada awal penanaman komoditi kelapa sawit yang ternyata membutuhkan waktu perawatan cukup banyak.

Kurang dari $50 \%$ petani berpendapat bahwa komoditi kelapa sawit cenderung tahan terhadap organisme pengganggu tanaman (OPT) dan hama penyakit tanaman (HPT) sehingga jarang terserang hama penyakit. Menurut petani komoditi kelapa sawit cenderung tahan terhadap hama dan penyakit dibandingkan komoditi karet. Di lokasi penelitian khusus untuk komoditi karet sering ditemukan hama dan penyakit yang menyerang tanaman karet petani sementara itu untuk komoditi kelapa sawit sejauh ini petani belum pernah mengalami permasalahan yang serius terkait dengan hama dan penyakit. Komoditi karet dinilai lebih rentan terhadap hama dan penyakit tersebut. Pada kenyataannya ternyata komoditi kelapa sawit juga memiliki hama dan penyakit yang sulit untuk dikendalaikan bahkan bisa mengakibatkan kerugian yang sangat besar contohnya serangan ulat api, ulat kantong dan lain sebagainya. Namun, fenomena tersebut belum pernah terjadi selama ini. Untuk HPT pada komoditi kelapa sawit dan komoditi karet terdapat hama pengganggu yang sama seperti monyet, babi dan belalang. Sebagian petani tidak sependapat dengan hal tersebut karena menurut petani komoditi kelapa sawit juga dapat terserang berbagai OPT dan HPT apabila tidak dirawat dengan baik.

Pengetahuan dan informasi yang dimiliki petani tentang hama dan penyakit pada komoditi kelapa sawit masih tergolong minim, hal ini dipengaruhi oleh pengalaman petani selama berusahatani kelapa sawit, karena petani belum pernah menemukan kasus OPT dan HPT yang serius dari tanaman kelapa sawit. Berdasarkan pengalaman petani saat petani mengusahakan komoditi karet hama yang menyerang lebih sulit di kendalikan dan menimbulkan kerugian yang cukup besar. Sementara untuk komoditi kelapa sawit belum ada permasalahan terkait hama penggangu yang menimbulkan kerugian yang besar. Jadi petani mempersepsikan hal ini hanya berdasarkan pengalaman selama berusahatani. Berdasarkan penjelasan diatas dan merujuk pada pendapat Rahmat (2004) yang menyatakan persepsi adalah pengalaman tentang objek, peristiwa atau hubungan-hubungan yang diperoleh dengan menyimpulkan informasi dan menafsirkan pesan. Petani dalam mempersepsikan sesuatu bukan hanya dari informasai yang diperolehnya pada saat itu melainkan dari berbagai pengalaman masa lalu serta meghubung-hubungkan informasi yang diperolehnya.

Petani juga mengusahakan usahatani karet dimana komoditi karet di lokasi penelitian banyak yang terserang jamur upas dan JAP yang sulit dikendalikan. Apabila tanaman karet yang terserang jamur maka tidak dapat diganti dengan tanaman karet melainkan harus diganti dengan tanaman lain dan petani pada umumnya memilih komoditi kelapa sawit sebagai pengganti komoditi karet yang terserang jamur tersebut agar jamur tidak dapat tumbuh dan berkembang biak kerena bukan merupakan tempat tumbuhnya. Solusi terakhir yang di ambil petani dengan berbagai pertimbangan adalah mengganti 
tanaman karet yang terserang jamur dengan tanaman kelapa sawit, sehingga di lokasi penelitian tidak jarang terlihat bahwa komoditi kelapa sawit berada dalam satu areal perkebunan dengan komoditi karet.

Dari keseluruhan petani tidak semua petani mempersepsikan hal yang sama terhadap komoditi kelapa sawit. Setiap petani memiliki pendapat masing-masing dan berbeda satu sama lain. Menurut hasil penelitian Suwantoro (2008) dalam Triyuyun (2011) mengemukakan bahwa persepsi petani yang berbeda dalam memandang sistem pertanian organik, anggapan petani tentang pertanian organik antara lain adalah pertanian organik dinilai merepotkan, petani memiliki keterampilan yang kurang memadai, pertanian organik belum terlindungi serta terdapat kegagalan menjaga kepercayaan pasar dan dukungan pemerintah yang masih kurang. Hal ini sejalan dengan pendapat Widayatun dan Rusmi (1999) yang menyatakan bahwa terdapat 4 hal yang mempengaruhi persepsi yaitu persepsi dalam belajar yang berbeda-beda, kesiapan mental dan kematangan usia, kebutuhan dan motivasi serta gaya berfikir yang berbeda-beda. Dari hasil penelitian dan teori yang dikemukakan diatas memperjelas bahwa persepsi yang berbeda-beda juga dipengaruhi oleh berbagai latar belakang pandangan petani dalam melihat suatu objek. Persepsi juga dipengaruhi oeleh pengalaman, kebiasaan dan kemampuan orang untuk mempersepsikan sesuatu, sehingga persepsi seseorang dengan orang yang lain berbeda-beda.

Persepsi merupakan anggapan langsung terhadap sesuatu, oleh sebab itu maka persepsi dapat diartikan sebagai tahap awal pembentukan keputusan petani dalam memilih dan mengembangkan usahataninya. Persepsi merupakan suatu cara orang dalam memandang dan menilai sesuatu secara sadar dengan cara menyeleksi atau mengatur semua informasi yang ada dan kemudian menafsirkannya untuk dapat menciptakan keseluruhan gambaran yang berarti (Leavitt dalam Sobur, 2009, Walgito, 2010, van Den Ban,1999, Rahmat, 2004). Persepsi yang didapatkan tentu saja memiliki berbagai alasan penunjang bahkan petani mengemukakan lebih dari 1 alasan terhadap argumen yang dikemukakannya dan antara petani yang satu dengan petani yang lain berbeda-beda.

Pada umumnya petani memilih komoditi yang diusahakannya berdasarkan anggapan terhadap komoditi tersebut menguntungkan atau tidak suatu komoditi tersebut di. Petani biasanya menggunakan pengalaman sebagai acuan dalam mempersepsikan sesuatu, sehingga bisa menimbulkan berbagai macam persepsi di antara petani dengan berbagai alternatif pemecahan masalah yang ditimbulkan. Kadang-kadang sebuah persepsi yang dominan juga mampu mempengaruhi persepsi petani yang lainnya terhadap suatu objek yang dipersepsikan. Petani bisa mempersepsikan sesuatu karena melihat keberhasilan ataupun kegagalan rekan sesama petani. Peran pemerintah juga menjadi pertimbangan petani dalam mempersepsikan sesuatu komoditi. Petani cenderung lebih tertarik apabila pemerintah mendukung penuh dengan memberikan penyuluhan dan bantuan dana dalam membantu pengembangan komoditi pertanian ataupun perkebunan yang dipilihnnya.

\section{Kesimpulan}

Persepsi petani terhadap komoditi kelapa sawit ditinjau dari aspek teknis yang telah diteliti memperlihatkan bahwa pada umumnya petani mempersepsikan komoditi kelapa sawit dari aspek teknis adalah menguntungkan karena teknologi yang digunakan mudah dimegerti dan teknik budidaya yang mudah, pada saat pemanenan hanya dibutuhkan waktu 1 kali dalam 2 minggu, organisme pengganggu tanaman dan hama penyakit tanaman lebih sedikit, jika dibandingkan dengan tanaman karet, tanaman kelapa sawit tidak terkena Jamur Akar Putih yang sulit dikendalikan seperti pada tanaman karet. Dari persepsi petani tersebut terlihat jelas bahwa petani masih menaruh minat yang besar terhadap pengembangan komoditi kelapa sawit sehingga pemerinta diharap dapat memberikan arahan dan penyuluhan dalam membina petani agar tetap produktif mengusahakan usahataninya dan mampu menguasai teknik budidaya yang baik dan sesuai dengan ketentuan yang ada.

\section{Daftar Pustaka}

Badan Pusat Statistik. 2009. Jambi Dalam Angka. BPS Provinsi Jambi.

Dinas Perkebunan Batanghari. 2008. Luas Perkebunan, Produksi dan Produktivitas Komoditi kelapa Sawit Perkecamatan di Kabupaten Batanghari tahun 2008. BPS Provinsi Jambi.

Dinas Perkebunan Provinsi Jambi. 2009. Jumlah Perkembangan Luas Tanaman Dan Produksi Tanaman Kelapa Sawit Di Provinsi Jambi tahun 
2005-2009. BPS Provinsi Jambi.

Edwina S dan Maharani E. 2010. Persepsi petani Terhadap Teknologi Pengolahan Pakan di Kecamatan Kerinci Kanan Kabupaten Siak. Indonesian journal of agriculture economics (IJAE). 2 (1): 169-183 [internet]. [diunduh 2015 Maret 7]. Tersedia pada: download.portalgaruda. org/article.php? article $=32000 \& v a l=2280$

Fauzi Y,Yustina EW, Satyawibawa I, Paeru RH.2008. Kelapa Sawit Budidaya dan Pemanfaatan Hasil dan Limbah Analisis Usaha dan Pemasaran. Jakarta (ID): Penebar Swadaya.

Hadiwijaya H. 2011. Persepsi siswa terhadap pelayanan jasa pendidian pada lembaga pendidikan El Rahma Palembang. Jurnal Ekonomi Dan Akutansi (Jenius). 1 (3): 221-237. Hamid H, Samah AA, Man N. 2013. The level of perceptions toward agriculture land development programme among Orang Asli in Pahang, Malaysia. Journal Asian Social Science. 9 (10): 151-159. doi:10.5539/ass.v9n10p151. [internet]. [diunduh 2014 november 23]. Terseda pada: http://www.ccsenet.org/journal/index.php/ass.

Garungan. 2009. Psikologi Sosial. Bandung (ID): Rafika Aditama

Kholiq, Hardiansyah, Djamaludin MD. 2008. Persepsi dan partisipasi dalam pengembangan lumbung pangan di Kabupaten Lampung Barat. Jurnal Gizi dan Pangan Institut Pertanian Bogor. 3 (3): 217-226 [internet]. [diunduh 2014 November 11]. Tersedia pada: http://journal.ipb. ac.id/index.php/jgizipangan.

Rahmat J. 2004. Psikologi Komunikasi. Bandung (ID): Remaja Rosdakarya.

Sihabudin A, Sugihen BG, Susanto P, Asngari PS. 2010. Pengaruh Interaksi Sosial Komunitas Adat Baduy Luar Terhadap Persepsinya Pada Kebutuhan Keluarga. Jurnal Penyuluhan. 6 (1).

Sobur A. 2009. Psikologi Umum. Bandung (ID): Pustaka Setia

Sunarko.2008. Petunjuk Praktis Budidaya dan Pengolahan Kelapa Sawit. Jakarta (ID): Agro Media Pustaka.

Triyuyun. 2011. Kajian Persepsi dan Perilaku Stakeholders terhadap Sistem Pertanian Padi Organik di Kabupaten Karanganyar. [Tesis]. Semarang: Universitas Diponegoro

van den Ban AW, Hawkins HS. 1999. Penyuluhan Pertanian. Yogyakarta (ID): Kanisius
Walgito B. 2010. Pengantar Psikologi Umum. Yogyakarta (ID): Penerbit ANDI .

Widayatun dan Rusmi T. 1999. Ilmu Perilaku. Jakarta (ID): Saging Seto 